\title{
Digestion Completeness of Microwave-Assisted and Conventional Trypsin-Catalyzed Reactions
}

\author{
P. Muralidhar Reddy, Wan-Yu Hsu, Jun-Fu Hu, and Yen-Peng Ho \\ Department of Chemistry, National Dong Hwa University, Hualien, Taiwan
}

Microwave-assisted proteolytic digestion often yields misscleaved peptides, attributed to incomplete hydrolysis reactions between enzymes and substrates. The number of missed cleavages is an important parameter in proteome database searching. This study investigates how various factors affect digestion processes. Optimum conditions for microwave-assisted digestion (50 mM Tris buffer, $30 \mathrm{~min}$ at $60^{\circ} \mathrm{C}$, and enzyme to protein molar ratio of 1:5) were determined. The digestion products obtained from eight standard proteins were characterized based on matrix-assisted laser desorption/ionization mass spectrometry (MALDI-MS). Experimental results indicate that the digestion temperature, reaction time, enzyme to substrate ratio, and digestion buffer affect the number of misscleaved peptides and incomplete digestion percentages. Although all protein molecules in a sample could be digested into peptides within a few minutes under microwave irradiation, longer reaction times or methods to maximize the enzyme activity should be considered if digestion completeness is a major concern. (J Am Soc Mass Spectrom 2010, 21, 421-424) (c) 2010 American Society for Mass Spectrometry

$\mathrm{A}$ $\mathrm{s}$ the most important proteomics approach, mass spectrometry (MS) has established its unique and indispensable role in analyzing proteins, owing to its accuracy, short analysis time, and high sensitivity. Protein characterization is typically performed using a "bottom-up" work flow, whereby proteins are subjected to proteolytic cleavage by chemical hydrolysis or enzymatic digestion. Effective digestion of these proteins often requires generating peptides in a minimal amount of time, with a high protein sequence coverage.

Conventional proteolytic digestion methods typically involve several hours or overnight incubations. A common practice is to adopt methods capable of reducing incubation times, while retaining high sequence coverage and enzymatic specificity. Methods of improving digestion efficiency include thermal denaturation [1] and chemical denaturation (i.e., detergents or acid-labile surfactants or organic solvents) $[2,3]$. Other methods to decrease proteolytic incubation times include using immobilized enzymes [4]. An alternative means of enhancing digestion efficiency involves using microwave irradiation [5]. This approach exploits unique microwave properties to accelerate the enzymatic digestion. In recent years, microwaveassisted proteolytic digestion procedures, including tryptic [6-8] and acid-mediated proteolysis [9-12], have enabled samples to be prepared more rapidly for bottom-up analysis.

Although the ability of microwave irradiation to accelerate enzymatic digestion is well established, digestion products obtained from microwave-assisted and conventional digestion have not been investigated in detail with

Address reprint requests to Dr. Y.-P. Ho, Department of Chemistry, National Dong Hwa University, Hualien 974, Taiwan, ROC. E-mail: ypho@mail.ndhu.edu.tw respect to the number of misscleaved peptides and incomplete digestion percentage. Microwave-assisted proteolytic digestion reactions often yield misscleaved peptides, resulting from incomplete hydrolysis reactions between enzymes and substrates. The number of missed cleavages is an important parameter in identification of proteins using proteome database searching. This study investigated how various solvents and reaction times, different enzyme to protein molar ratios, and varying microwave temperatures affected digestion processes.

\section{Experimental}

\section{Microwave Irradiation}

Microwave-assisted digestions were conducted with a CEM Discovery system (Matthews, NC, USA). The maximum output power of the microwave system is $300 \mathrm{~W}$ and the operating frequency is $2.5 \mathrm{GHz}$. The set reaction temperature was maintained by using a sensorcontrolled magnetron. The actual temperatures of reaction solutions were measured immediately with a thermocouple after microwave irradiation.

\section{Conventional/Microwave-Assisted Digestion}

Protein standards $(2 \mu \mathrm{g})$ were dissolved in $10 \mu \mathrm{L}$ of various digestion solvents and $1 \mu \mathrm{L}$ of urea $(6 \mathrm{M})$, reduced by $5 \mathrm{mM}$ dithiothreitol (DTT) at $56^{\circ} \mathrm{C}$ for $1 \mathrm{~h}$, and alkylated by $20 \mathrm{mM}$ iodoacetamide (IAA) in the dark room for $1 \mathrm{~h}$. All digestion solvents except for deionized water were adjusted to $\mathrm{pH}$ 8.6. For conventional digestion, proteins in $25 \mathrm{mM} \mathrm{NH}_{4} \mathrm{HCO}_{3}$ was digested by trypsin at 1:25 enzyme to protein molar ratio (E/S) and $37^{\circ} \mathrm{C}$ for 20 $\mathrm{h}$ in a water bath. For microwave-assisted digestion, protein 
solutions were digested with trypsin under CEM microwave irradiation at various temperatures. For in-gel digestion, proteins separated on a $12 \%$ SDS-polyacrylamide gel using a Bio-Rad Mini-Protean 3 system (Wellesley, MA, USA) were visualized with Coomassie brilliant blue G-250. The in-gel digestion was performed according to the method of Mann et al. [13].

\section{Mass Spectrometry}

MALDI matrix was prepared by dissolving $\alpha$-cyano-4hydroxycinnamic acid (CHCA) in a solvent mixture of 1:1 acetonitrile/ $0.1 \%$ TFA at a concentration of ca. $50 \mathrm{mM}$. Positive ion MALDI-mass spectra were acquired using an Autoflex time-of-flight (TOF) mass spectrometer (Bruker Daltonics, Bremen, Germany) equipped with a 337-nm nitrogen laser $(10 \mathrm{~Hz})$. Spectra when covering both peptide and protein mass ranges were obtained in the linear mode with an acceleration voltage of $20 \mathrm{kV}$ [14]. Spectra of peptide ions were acquired in the reflectron mode with an acceleration voltage of $19 \mathrm{kV}$. Each mass spectrum was derived from 100 summed scans.

\section{Results and Discussion}

Microwave-assisted proteolytic digestion has received increasing interest owing to its speed and convenience. This study compared how various solvents, temperatures, and different protein/enzyme molar ratios affect protein digestion under conventional heating and microwave irradiation. The digestion efficiencies (i.e., in-solution digestion as well as in-gel digestion) of several proteins with and without microwave irradiation are compared. Digestion efficiency refers to the ratio of the abundance of the most abundant peptide fragment to that of this peptide plus the undigested protein. The calculation assumes that the ionization efficiencies for peptide and protein ions are the same. Although this assumption is inaccurate, it provides a means to follow relative amounts of peptides and proteins during the digestion. Moreover, this study analyzes the number of misscleaved peptides (NMCP) resulting from incomplete hydrolysis reactions between enzymes and proteins as well as an incomplete digestion percentage (IDP) that is defined as the ratio between the abundance of peptides with missed cleavage site(s) and the total abundance of peptides detected.

Figure 1 illustrates MALDI-TOF mass spectra from the tryptic digest of myoglobin acquired from conventional and microwave-assisted digestion. Under conventional heating conditions $\left(25 \mathrm{mM} \mathrm{NH}_{4} \mathrm{HCO}_{3}, \mathrm{E} / \mathrm{S}\right.$ of 1: 25 at $37{ }^{\circ} \mathrm{C}$ for $20 \mathrm{~h}$ ), the digestion efficiency, sequence coverage, NMCP, and IDP were 100\%, 71\%, 4\%, and $8.1 \%$, respectively (Figure 1a). Under the same conditions, protein digestion with microwave irradiation was

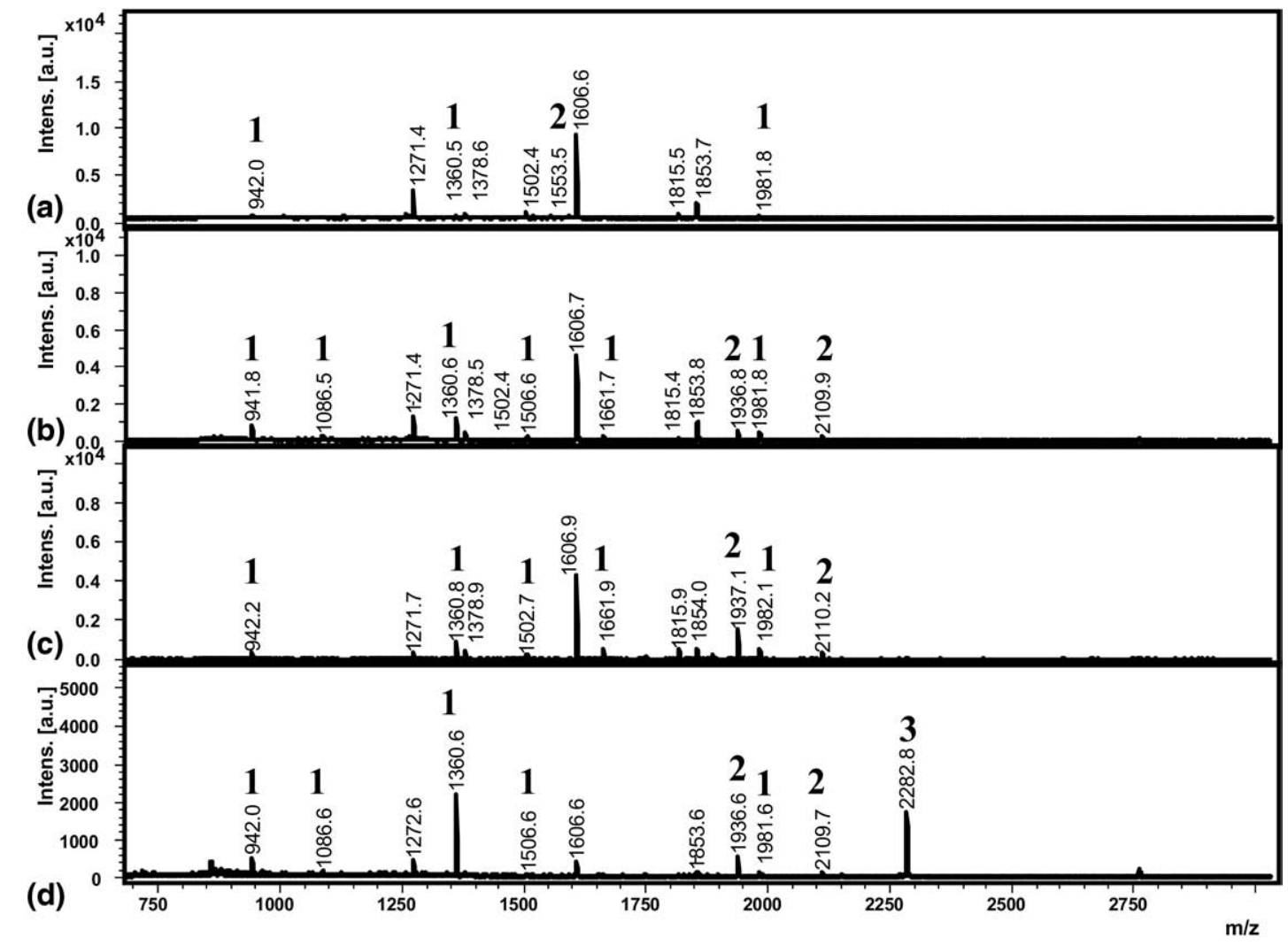

Figure 1. MALDI mass spectra of the tryptic digest of myoglobin obtained from digestion in $25 \mathrm{mM}$ $\mathrm{NH}_{4} \mathrm{HCO}_{3}$ with an E/S ratio of $1: 25$ under (a) conventional heating (at $37^{\circ} \mathrm{C}$ for $20 \mathrm{~h}$ ) and microwave irradiation at (b) $60{ }^{\circ} \mathrm{C}$, (c) $70^{\circ} \mathrm{C}$, and (d) $90^{\circ} \mathrm{C}$. The peaks marked 1, 2, and 3 correspond to the peptides with one, two, and three missed cleavage sites, respectively. 
performed at $60^{\circ} \mathrm{C}$ for $30 \mathrm{~min}$. For $30 \mathrm{~min}$ of microwave incubation, the digestion efficiency by definition is $100 \%$ because no protein signal was observed in the linear mode (data not shown). According to the mass spectrum shown in Figure 1b, sequence coverage was estimated to be $81 \%$. From those results, we can infer that microwave irradiation generated similar or better results than conventional heating because microwave irradiation yielded higher sequence coverage $(81 \%$ versus $71 \%$ ). However, NMCP for microwave heating conditions is eight out of 14 peptides observed, i.e., four more than that observed from conventional reaction conditions (four out of 10). This implies that the higher sequence coverage arises from longer peptides with missed cleavages. Furthermore, the IDP of microwave heating is $34.1 \%$, in contrast with $8.1 \%$, for conventional digestion. Experimental results indicate that more detailed and systematic investigations are required to understand how conventional and microwave heating differ in digestion efficiencies.

The digestion completeness is temperature-dependent. Figure $1 \mathrm{c}$ and d illustrate spectra of trypsin digestion of myoglobin at 70 and $90^{\circ} \mathrm{C}$, respectively. IDP at reaction temperatures of 60,70 , and $90^{\circ} \mathrm{C}$ are $34.1,39.2$, and 84.9, respectively. When the digestion temperature is $90^{\circ} \mathrm{C}$, a mass peak corresponding to three missed-cleavage sites is clearly observed. At a high temperature, in addition to the reaction occurring rapidly, the enzyme decreases its activity very quickly. The rapid loss of enzymatic activity may increase the percentage of incomplete digestion. This has implications when using domestic ovens to assist digestion, since the ovens lack temperature control.

The enzymatic reaction rate can be increased at an elevated temperature, and an optimum temperature range between 50 and $65{ }^{\circ} \mathrm{C}$ for trypsin digestion has been obtained [15]. Under our conditions, the reaction at $60^{\circ} \mathrm{C}$ for $30 \mathrm{~min}$ produced the optimum IDP. For instance, when myoglobin in $25 \mathrm{mM} \mathrm{NH}_{4} \mathrm{HCO}_{3}$ buffer and at an E/S ratio of 1:25 was digested for various digestion times (Figure 2), the value of IDP leveled off after $30 \mathrm{~min}$. Notably, although most proteins were digested into peptides, a fast reaction time did not allow as many cleavage sites as possible to be cleaved before the enzyme lost its activity. This explains why a longer digestion time did not improve IDP. The data were acquired in triplicate, and the error somewhat reflects the nature of MALDI experiments.

Figure 3 displays the IDP of myoglobin, lysozyme, and cytochrome $c$ digestion in $25 \mathrm{mM} \mathrm{NH}_{4} \mathrm{HCO}_{3}$ buffer under microwave irradiation at $60^{\circ} \mathrm{C}$ for $30 \mathrm{~min}$ and at various $\mathrm{E} / \mathrm{S}$ ratios. IDP decreases significantly when the $\mathrm{E} / \mathrm{S}$ ratio is changed from 1:25 to 1:5. IDPs are further decreased at higher E/S ratios. IDP for cytochrome $c$ at $\mathrm{E} / \mathrm{S}$ ratio of 1:1 does not reach a value as low as other proteins do because the IDP has reached the value obtained from conventional digestion. Although the reaction completeness was enhanced at higher E/S ratios, the autolysis product of trypsin became obvious

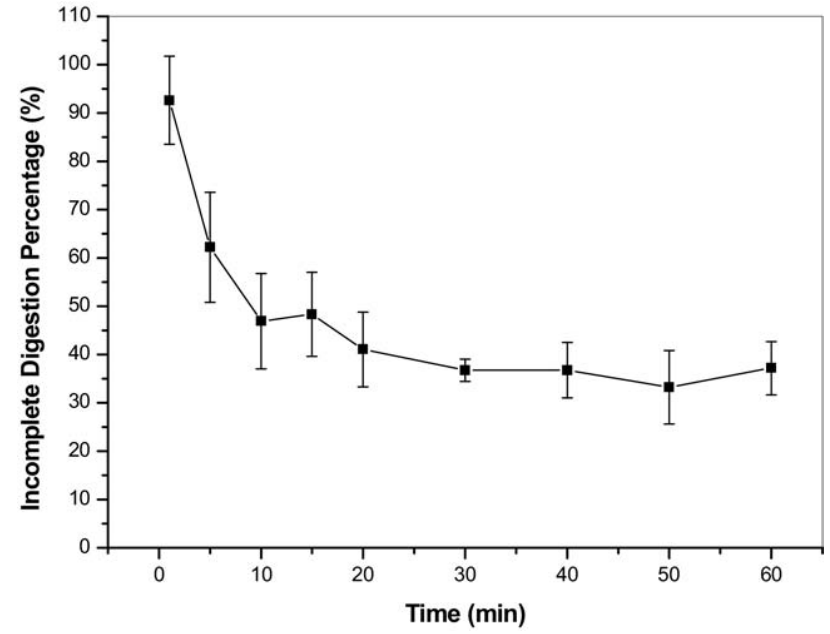

Figure 2. Incomplete digestion percentage of myoglobin digestion in $25 \mathrm{mM} \mathrm{NH} \mathrm{HCO}_{3}$ with an E/S ratio of 1:25 under microwave irradiation at $60^{\circ} \mathrm{C}$ as a function of digestion time.

when the E/S ratios of 1:1 and 1:2 were used. Trypsin autolysis products were insignificant under the conditions used, where the $\mathrm{E} / \mathrm{S}$ ratio was 1:5 and the reaction time was $30 \mathrm{~min}$.

This study attempts to further improve the digestion by selecting various solvents at different $\mathrm{E} / \mathrm{S}$ ratios $(\mathrm{E} / \mathrm{S}=$ $1 / 25$ and $1 / 5$ ) under the same temperature at $60^{\circ} \mathrm{C}$. Supplementary Table S1, which can be found in the electronic version of this article, summarizes the NMCP, digestion efficiency, sequence coverage, and IDP of myoglobin in various solvent systems at different enzyme-toprotein ratios (1:25/1:5) under microwave irradiation for $30 \mathrm{~min}$. According to Table S1, when $\mathrm{E} / \mathrm{S}=1: 25$, the digestion efficiency is $100 \%$ in ammonium bicarbonate as well as 50 and $100 \mathrm{mM}$ Tris buffers. The digestion is not complete in solvents such as pure water, $65 \% 50 \mathrm{mM}$ Tris in acetonitrile (ACN), $50 \% 25 \mathrm{mM} \mathrm{NH}_{4} \mathrm{HCO}_{3}$ in $\mathrm{ACN}$, and $50 \% 25 \mathrm{mM} \mathrm{NH}_{4} \mathrm{HCO}_{3}$ in methanol (MeOH). Pure water without a $\mathrm{pH}$ buffering solution does not appear to be as effective as a $\mathrm{pH}$ buffered aqueous solvent for digestion. According to a previous study, organic solvent-containing solutions denature proteins and increase the sequence coverage of protein digests [2]. The linear-mode spectra of the tryptic digest of myoglobin in the $\mathrm{ACN}-$ and $\mathrm{MeOH}-$ containing solvents include many large peptide fragments with $\mathrm{m} / \mathrm{z}$ exceeding 3000 and an abundance of undigested protein (data not shown). The digestion efficiency is less than $50 \%$ for the solvents of $50 \% 25 \mathrm{mM} \mathrm{NH}_{4} \mathrm{HCO}_{3}$ in $\mathrm{ACN}$, and $50 \% 25 \mathrm{mM} \mathrm{NH}_{4} \mathrm{HCO}_{3}$ in $\mathrm{MeOH}$.

Based on the data from Table $\mathrm{S} 1$, the sequence coverage of myoglobin in $\mathrm{NH}_{4} \mathrm{HCO}_{3}$ as well as $50 \mathrm{mM}$ and $100 \mathrm{mM}$ Tris buffers under microwave heating provided a higher sequence coverage than that obtained from the conventional method. Furthermore, all NMC and IDP of microwave heating are higher than those observed from the conventional digestion method. Overall, when E/S = 1:5, the IDP and NMCP decrease, particularly in $50 \mathrm{mM}$ Tris buffer. NMCP in $50 \mathrm{mM}$ Tris buffer for the microwave 


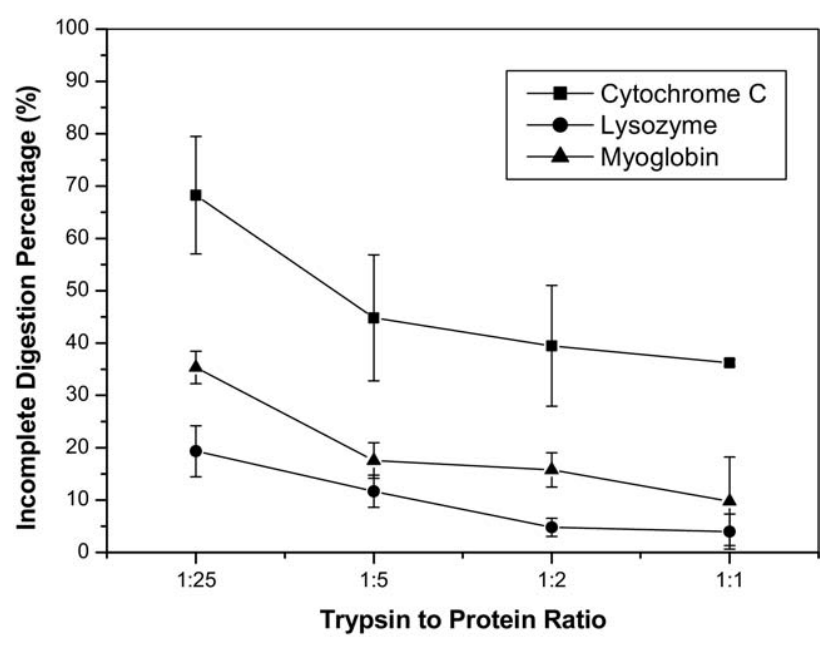

Figure 3. Incomplete digestion percentage of microwaveassisted myoglobin, cytochrome $c$, and lysozyme digestion at $60^{\circ} \mathrm{C}$ for $30 \mathrm{~min}$ versus various $\mathrm{E} / \mathrm{S}$ ratios.

condition is five out of 12 peptides observed, i.e., slightly more but close to that from the conventional digestion, where NMC is four out of 10. IDP of microwave irradiation is $8.9 \%$, in contrast with $8.1 \%$ for the conventional digestion method. The enzyme likely has higher proteolytic activity in $50 \mathrm{mM}$ Tris buffer than in $50 \mathrm{mM}$ $\mathrm{NH}_{4} \mathrm{HCO}_{3}$. The dependence of enzymatic activity on buffers is known, and has been described for enzymes such as angiotensin-converting enzyme [16].

Supporting information in Tables S2-S5 presents $\mathrm{NMC}$, digestion efficiency, sequence coverage, and IDP of cytochrome $c /$ lysozyme in various solvent systems at different enzyme-to-protein ratios under microwave irradiation. The digestion in $50 \mathrm{mM}$ Tris buffer, at E/S ratio of $1: 5$, and under microwave irradiation at $60{ }^{\circ} \mathrm{C}$ for $30 \mathrm{~min}$ consistently yielded a relatively low NMC and IDP. To verify the consistency of the optimum conditions, this study applies these conditions to five other proteins. NMC, digestion efficiency, sequence coverage, and IDP of ubiquitin, ribonuclease A, $\alpha$-casein, albumin and transferrin in $50 \mathrm{mM}$ Tris buffer under microwave at $60{ }^{\circ} \mathrm{C}$ for $30 \mathrm{~min}$ with an $\mathrm{E} / \mathrm{S}$ ratio of $1: 5$ (data not shown) are all similar to those obtained from the conventional digestion method.

In addition to in-solution digestion, this study also investigated in-gel digestion under microwave irradiation. Microwave-assisted in-gel digestion in $50 \mathrm{mM}$ Tris buffer with an E/S ratio of 1:5 did reduce the NMP (Supplementary Fig. S1,). Supplementary Table S6 summarizes the digestion data from various proteins. The results are parallel to those of in-solution digestion. Figure S2 illustrates the parallel characteristics. In addition to the parallel characteristics, the IDP for in-gel digestion is generally higher than for in-solution digestion because the contact of enzyme with substrates is relatively difficult for in-gel digestion.

\section{Conclusions}

Under microwave irradiation, digestion completeness depends on factors, including digestion temperature, reaction time, enzyme to substrate ratio, and digestion buffer. Notably, although all protein molecules in a sample could be digested into peptides within a few minutes under microwave irradiation, the number of miss-cleaved peptides and incomplete digestion percentages were often higher than those when the reaction times were longer than a few minutes. Therefore, a reaction time as long as $30 \mathrm{~min}$ or methods to maximize the enzyme activity should be considered if digestion completeness is a major concern.

\section{Acknowledgments}

The authors thank the National Science Council of the Republic of China for financial support of this research.

\section{Appendix A Supplementary Material}

Supplementary material associated with this article may be found in the online version at doi:10.1016/ j.jasms.2009.11.006.

\section{References}

1. Park, Z. Y.; Russell, D. H. Thermal denaturation: A Useful Technique in Peptide Mass Mapping. Anal. Chem. 2000, 72, 2667-2670.

2. Russell, W. K.; Park, Z. Y.; Russell, D. H. Proteolysis in Mixed OrganicAqueous Solvent Systems: Applications for Peptide Mass Mapping Using Mass Spectrometry. Anal. Chem. 2001, 73, 2682-2685.

3. Yu, Y. Q.; Gilar, M.; Lee, P. J.; Bouvier, E. S. P.; Gebler, J. C. EnzymeFriendly, Mass Spectrometry-Compatible Surfactant for In-Solution Enzymatic Digestion of Proteins. Anal. Chem. 2003, 75, 6023-6028.

4. Massolini, G.; Calleri, E. Immobilized Trypsin Systems Coupled OnLine to Separation Methods: Recent Developments and Analytical Applications. J. Sep. Sci. 2005, 28, 7-21.

5. Lill, J. R.; Ingle, E. S.; Liu, P. S.; Pham, V.; Sandoval, W. N. MicrowaveAssisted Proteomics. Mass Spectrom. Rev. 2007, 26, 657-671.

6. Pramanik, B. N.; Mirza, U. A.; Ing, Y. H.; Liu, Y. H.; Bartner, P. L.; Weber, P. C.; Bose, M. K. Microwave-Enhanced Enzyme Reaction for Protein Mapping by Mass Spectrometry: A New Approach to Protein Digestion in Minutes. Protein Sci. 2002, 11, 2676-2687.

7. Juan, H. F.; Chang, S. C.; Huang, H. C.; Chen, S. T. A New Application of Microwave Technology to Proteomics. Proteomics 2005, 5, 840-842.

8. Chen, W.-Y.; Chen, Y.-C. Acceleration of Microwave-Assisted Enzymatic Digestion Reactions by Magnetite Beads. Anal. Chem. 2007, 79, 2394-2401.

9. Hua, L.; Low, T. Y.; Sze, S. K. Microwave-Assisted Specific Chemical Digestion for Rapid Protein Identification. Proteomics 2006, 6, 586-591.

10. Zhong, H.; Zhang, Y.; Wen, Z.; Li, L. Protein Sequencing by Mass Analysis of Polypeptide Ladders after Controlled Protein Hydrolysis. Nat. Biotech. 2004, 22, 1291-1296.

11. Hauser, N. J.; Basile, F. On-Line Microwave D-Cleavage LC-ESI-MS/MS of Intact Proteins: Site-Specific Cleavages at Aspartic Acid Residues and Disulfide Bonds. J. Proteome Res. 2008, 7, 1012-1026.

12. Swatkoski, S.; Gutierrez, P.; Wynne, C.; Petrov, A.; Dinman, J. D.; Edwards, N.; Fenselau, C. Evaluation of Microwave-Accelerated Residue-Specific Acid Cleavage for Proteomic Applications. J. Proteome Res. 2008, 7, 579-586.

13. Shevchenko, A.; Wilm, M.; Vorm, O.; Mann, M. Mass Spectrometric Sequencing of Proteins from Silver Stained Polyacrylamide Gels. Anal. Chem. 1996, 68, 850-858.

14. Lin, S.-S.; Wu, C.-H.; Sun, M.-C.; Sun, C.-M.; Ho, Y.-P. MicrowaveAssisted Enzyme-Catalyzed Reactions in Various Solvent Systems. J. Am. Soc. Mass Spectrom. 2005, 16, 581-588.

15. Havlis, J.; Thomas, H.; Sebela, M.; Shevchenko, A. Fast-Response Proteomics by Accelerated In-Gel Digestion of Proteins. Anal. Chem. 2003, 75, 1300-1306.

16. Bala, M.; Gupta, S.; Pasha, M. A. W. Angiotensin-Converting Enzyme Assay Optimization: Influence of Various Buffers and Their Concentrations. Clin. Biochem. 2000, 33, 687-689. 